УДК 342.9

\author{
Ю. М. Ольшевська \\ orcid.org/0000-0001-9642-9255 \\ студентка Інституту права \\ Київського національного університету імені Тараса Шевченка
}

А.І. Берлач

orcid.org/0000-0003-0986-4764

доктор юридичних наук, професор, заслужений юрист України, завідувач кафедри службового та медичного права

Київського національного університету імені Тараса Шевченка

\title{
МАТЕРІАЛЬНА ВІДПОВІДАЛЬНІСТЬ ДЕРЖАВНИХ СЛУЖБОВЦІВ ЗА ЧИННИМ ЗАКОНОДАВСТВОМ УКРАЇНИ
}

Масштабне реформування публічного управління держави протягом останніх років включає в себе й внесення змін до правового регулювання матеріальної відповідальності державних службовців. Це питання є актуальним, оскільки відповідальність службовців за вчинені ними діяння, які завдали шкоду, $є$ механізмом забезпечення дотримання прав особами, уповноваженими виконувати функції держави, а також сприяє формуванню високого рівня при розробці та впровадженні управлінських рішень органами публічної влади та їхніми посадовими і службовими особами.

Українське суспільство перебуває на стадії обговорення та прийняття нового Трудового кодексу, що має врегулювати велику кількість питань, на які не поширюються норми діючого трудового законодавства, в тому числі це стосується й інституту відповідальності службових і посадових осіб державних і муніципальних органів влади. Саме встановлення ефективного парового механізму відповідальності державних службовців є додатковою запорукою недопущення в їхній діяльності порушення прав і законних інтересів як держави, так і окремих громадян.

Метою роботи $\epsilon$ аналіз правових норм, які регулюють матеріальну відповідальність у чинному законодавстві України.

Аналіз останніх досліджень і публікацій. Обраною проблематикою серед вітчизняних правознавців займалися І.А. Кліпацька, А.Ю. Коротких, В.Л. Костюк, М.М. Левенець, які розглянули окремі аспекти питання матеріальної відповідальності державних службовців у нашій державі.

Виклад основного матеріалу. Нині наша держава знаходиться в умовах економічної кризи та розгортання антикорупційної реформи, що потребує не лише превенції порушень на державній службі, але й оперативного реагування на порушення чинного законодавства державними службовцями, вимагає оптимальних дій щодо ефективного й оперативного покриття шкоди, яка була завдана державі такими порушеннями законодавства. У зв'язку з цим виникає потреба в переосмисленні матеріальної відповідальності державних службовців відповідно до вимог часу [7, с. 16-17]. Здійснення в Україні інституційної реформи державної служби, якісне та системне переосмислення іï мети, завдань і повноважень в умовах громадянського суспільства тісно пов'язане із системним реформуванням правового становища державних службовців [9, с. 44].

Загалом матеріальна відповідальність є складником правового механізму забезпечення дотримання суб'єктами, які є учасниками правовідносин, визначеної чи допустимої правовими нормами поведінки. Матеріальна відповідальність як один із видів юридичної відповідальності в широкому сенсі становить собою обов'язок однієї зі сторін відшкодовувати відповідно до законодавства майнову шкоду, заподіяну іншій стороні трудового договору внаслідок порушення обов'язків у трудових правовідносинах і виникає лише в результаті винуватого порушення своїх обов'язків суб'єктами трудових правовідносин, тобто внаслідок вчинення ними трудового правопорушення [7, с. 17].

В.Л. Костюк зазначає, що матеріальна відповідальність $є$ превентивно-попереджувальним фактором належного виконання державними службовцями своїх обов'язків. Насамперед вона передбачає понесення державним службовцем негативних наслідків майнового характеру. При цьому дослідник зауважує, що є певні суперечності щодо законодавчої допустимості застосування принципів цивільно-правової відповідальності до матеріальної відповідальності посадових осіб, у тому числі державних службовців.

Специфічним для матеріальної відповідальності державних службовців як суб'єктів службового права є те, що такі суб'єкти можуть бути притягнутими до матеріальної відповідальності в результаті вчинення ними службового проступку, яким було завдано державі матеріальної шкоди [6, с. 45]. А.Ю. Коротких наголошує, що головною особливістю змісту матеріальної від- 
повідальності державних службовців є специфіка правового статусу державних службовців як суб'єктів трудового права в Україні, що виражається в особливостях трудових правовідносин, які виникають між державним службовцем-працівником і наймачем (державою в особі наймача, органу), з урахуванням ч. 2 ст. 3 Закону України «Про державну службу» [7, с. 17].

Таким чином, правовою основою матеріальної відповідальності державних службовців є норми ст. 56 Конституції України, які закріплюють за кожним право на відшкодування за рахунок держави чи органів місцевого самоврядування матеріальної та моральної шкоди, завданої незаконними рішеннями, діями чи бездіяльністю органів державної влади, органів місцевого самоврядування, їх посадових і службових осіб при здійсненні ними своїх повноважень [4].

Матеріальна відповідальність є різновидом цивільно-правової відповідальності. До матеріальної відповідальності можуть бути притягнуті фізичні особи, тобто посадові чи службові особи державного чи муніципального органу, в порядку, визначеному законодавством. Так, у рішенні Печерського районного суду м. Києва від 24.09.2020 по справі № 757/66154/19-ц зазначено, що підставою для цивільно-правової відповідальності (матеріальної відповідальності держави в особі державного виконавця) за завдання шкоди у такому випадку є правопорушення, яке включає як складники шкоди, протиправне діяння особи, яка її завдала, причинний зв'язок між ними, а шкода відшкодовується незалежно від вини [11].

Матеріальна відповідальність державного службовця закріплена у ч. 1 ст. 81 Закону України «Про державну службу». Так, службовець зобов'язаний відшкодувати державі шкоду, заподіяну внаслідок неналежного виконання ним посадових обов'язків. А.Ю. Коротких зазначає, що матеріальна відповідальність за вчинені діяння настає незалежно від притягнення працівника до дисциплінарної, адміністративної чи кримінальної відповідальності [5, с. 23].

Так, у рішенні Одеського окружного адміністративного суду від 16.11.2020 по справі № 420/5531/20 вказано, що через неналежне виконання посадових обов'язків працівником Державної служби з лікарських засобів та контролю за наркотиками в Одеській області було завдано матеріальну шкоду (нарахування неналежних надбавок працівникам державного органу за інтенсивність праці), що було виявлено під час перевірки фінансової звітності й відкрито дисциплінарне провадження. Державний орган звернувся до суду з позовом про відшкодування шкоди в порядку регресу, який було задоволено відповідно до положень ст. 80 Закону України «Про державну службу» та ст. 1191 Цивільного кодексу України [11].
Доцільно погодитися і з твердженням М.М. Левенець, яка наголошує, що оскільки матеріальна шкода заподіюється державним службовцем особисто (порушення своїх посадових обов'язків), держава наділяється правом зворотної вимоги до цієї посадової особи за відшкодовану нею шкоду [9, с. 142]. Ця норма ч. 2 ст. 80 Закону України «Про державну службу» цілком відповідає змісту норми ч. 4 ст. 1191 Цивільного кодексу України (далі - ЦК України). Матеріальна відповідальність працівника, в тому числі й державного службовця, настає лише за пряму дійсну шкоду в межах і порядку, визначеному чинним законодавством відповідно до ч. 1 ст. 130 Кодексу законів про працю України (далі - КЗпП України) [3]. I.A. Кліпацька наголошує, що підставою притягнення до матеріальної відповідальності є заподіяння певного матеріального збитку [2, с. 149]. Також необхідно враховувати, що матеріальна шкода відшкодовується приватним особам державою за рішенням суду [2, с. 149].

У цьому випадку в держави виникає право вимагати у винної особи - працівника відшкодування витрат, пов'язаних із компенсацією шкоди, завданої незаконними рішеннями, діями чи бездіяльністю службовими чи посадовими особами при виконанні обов' язків, покладених на них, що закріплено в ч. 2 ст. 81 Закону України «Про державну службу». Варто зауважити, що державний службовець у випадку завдання шкоди відшкодовує тільки застосування зворотної вимоги (регресу). Державний службовець несе матеріальну відповідальність лише за шкоду, умисно заподіяну його протиправними діями або бездіяльністю [1].

Так, у рішенні Черкаського окружного адміністративного від 22.07.2019 по справі № 580/1444/19 зазначено, що відповідно до положень ст. 80 Закону України «Про державну службу" в разі застосування зворотної вимоги (регресу) державою державний службовець несе матеріальну відповідальність тільки за шкоду, умисно заподіяну його протиправними діями або бездіяльністю, і не несе відповідальності за протиправні дії інших службовців чи керівника органу. Тобто лише за власні діяння особа притягається до матеріальної відповідальності. Якщо ж особі було завдано матеріальної шкоди протиправним рішенням (дисциплінарним стягненням, наприклад, позбавлення премії і надбавок до заробітної плати), то в особи виникає право звернутися до суду на підставі ст. 56 Конституції України.

Зауважимо, що за загальним правилом, яке закріплено в ч. 4 ст. 1191 ЦК України, шкода, завдана працівником третім особам (особам, 3 якими працівник не перебуває в трудових відносинах), неналежним виконанням своїх трудових обов'язків покривається державою в особі суб'єкта призначення [13]. При цьому після по- 
криття матеріальної шкоди третій особі (зокрема, відшкодування шкоди їх майну, здоров'ю, виплаченої пенсії, допомоги по соціальному страхуванню) підприємство, установа чи організація, перед якою винний працівник несе матеріальну відповідальність, може притягнути його до такої відповідальності у порядку регресу за нормами трудового законодавства [13].

Аналогічні норми закріплені в ст. 80 Закону України «Про державну службу». Так, матеріальна та моральна шкода, заподіяна фізичним i юридичним особам незаконними рішеннями, діями чи бездіяльністю державних службовців під час здійснення ними своїх повноважень, відшкодовується за рахунок держави [1]. Така ж норма про матеріальну відповідальність працівника за заподіяну матеріальну шкоду закріплена у ст. 130 КЗпП України. Зокрема, у статті зазначено, що працівники несуть матеріальну відповідальність за шкоду, заподіяну підприємству, установі, організації внаслідок порушення покладених на них трудових обов'язків [3].

Доцільно зауважити, що згідно з ч. 2 ст. 80 Закону України «Про державну службу» право до винної службової чи посадової особи вимагати зворотного відшкодування витрат держави (регрес), її органу виникає в суб’єкта призначення до винної особи, яка заподіяла шкоду, або посадової особи (осіб), винної (винних) у незаконному звільненні, відстороненні або переведенні державного службовця чи іншого працівника на іншу посаду, щодо відшкодування матеріальної та моральної шкоди, заподіяної державному органу у зв'язку з оплатою часу вимушеного прогулу або часу виконання нижче оплачуваної роботи [1].

У рішенні Окружного адміністративного суду м. Києва від 27.05.2020 по справі № 640/8119/19 зазначено, що відшкодування шкоди може вимагати лише особа, якій їі було завдано, тобто вона є суб'єктом (носієм) порушених прав, свобод чи інтересів. Тому для того, щоб особі було надано судовий захист, суд встановлює, чи дійсно щодо особи має місце факт порушення права, свободи чи інтересу, чиє це право, свобода або інтерес порушеними [14]. Фактично лише держава або iï уповноважений орган має право звернутися до суду з позовом про відшкодування шкоди в порядку регресу. Таким чином, загальний порядок процедури покриття шкоди, заподіяної працівником, визначено в ст. 136 КЗпП України, але процедура притягнення до матеріальної відповідальності державного службовця має свої особливості, закріплені у законодавстві.

Так, згідно положень ст. 82 Закону України «Про державну службу» для відшкодування шкоди керівник органу державної служби вносить державному службовцю письмову пропозицію, в якій зазначаються розмір, порядок і строки від- шкодування шкоди, а також обставини, що стали підставою для відшкодування. Державний службовець повинен дати відповідь на пропозицію про добровільне відшкодування шкоди у письмовій формі. У разі ненадання державним службовцем відповіді на пропозицію про добровільне відшкодування шкоди, відмови від відшкодування шкоди чи невідшкодування шкоди до зазначеного у пропозиції строку керівник державної служби може звернутися з позовом про таке відшкодування до суду. М.М. Левенець зазначає, що такий механізм дозволяє оперативно та добровільно на досудовій стадії вирішити проблему відшкодування [8, с. 142]. Тим більше, що ця норма закону цілком відповідає приписам ч. 3 ст. 124 Конституції України, де вказано, що законом може бути визначений обов' язковий досудовий порядок врегулювання спору [4].

Згідно з ч. 4 ст. 81 Закону України «Про державну службу» під час визначення розміру відшкодування шкоди враховується майнове становище державного службовця, стаж його роботи, розпорядження та накази, отримані державним службовцем, співвідношення розміру заподіяної шкоди до його заробітної плати, ризик виникнення шкоди [1]. Тільки за таких умов розмір шкоди та її відшкодування можуть бути обгрунтованими.

Відповідно до приписів ч. 3 ст. 81 Закону України «Про державну службу», якщо шкода заподіяна кількома державними службовцями, то відповідальність пропорційна ступеню вини кожного 3 них [1]. Матеріальна відповідальність здебільшого повинна обмежуватися певною частиною заробітку державного службовця у розмірі прямої дійсної шкоди, завданої діяннями винної особи, i не може перевищувати середнього місячного заробітку, крім випадків, передбачених законодавством [7, с. 19].

Необхідно зазначити, що законодавство не містить роз'яснення цього терміну, однак воно отримало своє визначення в судовій практиці. Так, згідно Постанови Пленуму Верховного Суду № 14 «Про судову практику у справах про відшкодування шкоди, заподіяної підприємствам, установам, організаціям їхніми працівниками» від 29 грудня 1992 року під поняттям «прямої дійсної шкоди» слід розуміти втрату, погіршення або зниження цінності майна, необхідність для державного підприємства, установи, організації провести затрати на відновлення, придбання майна чи інших цінностей або провести зайві, тобто викликані внаслідок порушення працівником трудових обов' язків, грошові виплати [10].

Так, відповідно до норм ст. 1192 ЦК суд може зобов' язати особу, яка завдала шкоди майну, відшкодувати її в натурі (передати річ того ж роду і такої ж якості, полагодити пошкоджену річ тощо) або відшкодувати завдані збитки у повному обсязі [13]. 
Згідно ст. 1191 ЦК розмір збитків, що підлягають відшкодуванню потерпілому, визначається відповідно до реальної вартості втраченого майна на момент розгляду справи або виконання робіт, необхідних для відновлення пошкодженої речі [13]. Держава може в порядку зворотної вимоги до винного державного службовця вимагати на підставі рішення суду відшкодувати вартість пошкодженого чи втраченого майна або робіт для його відновлення, тобто своїх витрат по відшкодуванню перед третьою особою, якій було реально завдано шкоди.

При цьому є кілька неврегульованих і суперечливих аспектів інституту матеріальної відповідальності державних службовців у вітчизняному законодавстві. I.А. Кліпацька зауважує, що здається недоцільним віднесення відшкодування моральної шкоди в межах матеріальної відповідальності, оскільки остання головною своєю підставою передбачає заподіяння певного матеріального збитку [2, с. 149]. Це зауваження є слушним, оскільки моральна шкода насамперед полягає у фізичному болі та душевних стражданнях. Однак дослідниця зазначає, що все-таки необхідно враховувати, що як матеріальна шкода, так і моральна шкода відшкодовуються приватним особам державою за рішенням суду [2, с. 149].

В.Л. Костюк зазначає, що немає чіткого визначення співвідношення норм Закону України «Про державну службу» та норм трудового законодавства щодо питання притягнення до матеріальної відповідальності [8, с. 47]. Також варто зазначити, що законодавець чітко не вирішив питання щодо обсягу можливих відшкодувань державними службовцями, а саме чи включається пряма дійсна шкода, чи підлягають відшкодуванню, в тому числі, неодержані прибутки. До того ж у вітчизняному законодавстві відсутні норми, які регулюють процедуру оскарження рішень про притягнення державних службовців до матеріальної відповідальності.

Висновки. Матеріальна відповідальність державних службовців є специфічними видом юридичної відповідальності, яка настає незалежно від притягнення державного службовця до кримінальної, адміністративної чи дисциплінарної відповідальності. Насамперед матеріальна відповідальність відрізняється від усіх інших видів відповідальності своїм не каральним, а саме правовідновлювальним характером, тому вона може накладатися тоді, коли є реальна, передбачена законодавством потреба в матеріальній компенсації, відшкодуванні нанесеної шкоди. Державні службовці у випадках, визначених законодавством, можуть відшкодовувати як шкоду, нанесену державі своїми діями чи бездіяльністю, так і в порядку зворотної вимоги (регресу) шкоду, яку держава компенсувала третім особам, яким було нанесено збиток діями чи бездіяльністю державними службовцями.

\section{Jimepamypa}

1. Про державну службу. Закон України від 10.12.2015 / Верховна Рада України. URL: https://zakon.rada.gov.ua/laws/show/889-19\#Text (дата звернення: 01.03.2021).

2. Кліпацька I.A. Матеріальна відповідальність державних службовців: процедурний і процесуальний аспекти. Верховенство права очима правників-початківиів : матер. Всеукр. наук. конфер. студентів та аспірантів (м. Одеса, 18 листопада 2017 року). Одеса. 2017. C. $148-151$.

3. Кодекс законів про працю України від 10.12.1971 / Верховна Рада України. URL: https:// zakon.rada.gov.ua/laws/show/322-08\#Text (дата звернення: 01.03.2021).

4. Конституція України від 28.06.1996. URL: https://zakon.rada.gov.ua/laws/show $/ 254 \%$ D0 $\%$ BA $/ 96-\%$ D0 $\%$ B2 $\%$ D1\% 80\#Text (дата звернення: 01.03.2021).

5. Коротких А.Ю. Юридична відповідальність державних службовців за трудовим законодавством України: теорія, практика, проблеми. Харків : Константа, $2019.420 \mathrm{c}$.

6. Коротких А.Ю. Види матеріальної відповідальності державних службовців за шкоду, заподіяну державі. Боротьба з організованою злочинністю $і$ корупиією (теорія і практика). 2015. № 2. С. 45-50.

7. Коротких А.Ю. Особливості змісту матеріальної відповідальності державних службовців. Соціальне право. 2019. № 1. С. 66-73.

8. Костюк В.Л. Матеріальна відповідальність державних службовців за новітнім законодавством: проблеми та перспективи. Дні науки Національного університету "Києво-Могилянська академія" на факультеті правничих наук, 2016 : тези наукових доповідей і повідомлень, 3 лютого 2016 року. Київ, 2016. C. $44-48$.

9. Левенець М.М. Матеріально-правова відповідальність державних службовців: національний і зарубіжний досвід. Соціально-гуманітарний вісник. 2018. Вип. 24. С. 141-143. URL: http://nbuv.gov.ua/UJRN/ sochumj_2018_24_93 (дата звернення: 01.03.2021).

10. П̄ро судову практику в справах про відшкодування шкоди, заподіяної підприємствам, установам, організаціям іхніми працівниками. Постанова Пленуму Верховного Суду № 14 від 29 грудня 1992 року. URL: https://zakon.rada.gov.ua/laws/show/ v0014700-92\#Text (дата звернення: 01.03.2021).

11. Рішення Печерського районного суду м. Києва від 24.09.2020 по справі № $757 / 66154 / 19$-ц. URL: https://reyestr.court.gov.ua/Review/92178904 (дата звернення: 14.03.2021).

12. Рішення Одеського окружного адміністративного суду від 16.11.2020 по справі № 420/5531/20. URL: https://reyestr.court.gov.ua/Review/92889605 (дата звернення: 14.03.2021).

13. Рішення Черкаського окружного адміністративного від 22.07.2019 по справі № 580/1444/19. URL: https://reyestr.court.gov.ua/Review/83266138 (дата звернення: 14.03.2021).

14. Рішення Окружного адміністративного суду м. Києва від 27.05.2020 по справі № 640/8119/19. URL: https://reyestr.court.gov.ua/Review/90298004 (дата звернення: 14.03.2021).

15. Цивільний кодекс України від 16.01.2003 / Верховна Рада України. URL: https://zakon.rada.gov.ua/ laws/show/435-15\#Text (дата звернення: 01.03.2021). 


\section{Анотація}

Ольшевська Ю. М., Берлач А. І. Матеріальна відповідальність державних службовців за чинним законодавством України. - Стаття.

У статті розглянуто особливості інституту матеріальної відповідальності державних службовців за нормами чинного законодавства. Автором проаналізовано особливості процедури, підстави та порядок притягнення до матеріальної відповідальності державних службовців, висвітлено співвідношення норм Закону України «Про державну службу» та актів трудового законодавства. Розглянуто підходи вітчизняних науковців до розуміння правової природи інституту матеріальної відповідальності державних службовців, а також значення положень Постанови Пленуму Верховного Суду № 14 «Про судову практику в справах про відшкодування шкоди, заподіяної підприємствам, установам, організаціям їхніми працівниками" від 29 грудня 1992 року при застосуванні до притягнення до матеріальної відповідальності державних службовців як суб'єктів трудового права.

Автор доходить висновку, що матеріальна відповідальність $€$ засобом забезпечення дотримання посадовими та службовими особами вимог законодавства та правил внутрішнього розпорядку, посадових інструкцій. Також вона дозволяє компенсувати шкоду, понесену публічними органом або державою у зв'язку з вчиненням службового проступку її посадовою службовою особою. Характерною особливістю інституту матеріальної відповідальності державних службовців є особливості правового статусу державних службовців як суб'єктів службового права. Насамперед вона полягає у тому, що відповідно до норм Конституції шкода, завдана рішеннями чи діяльністю державного органу, його посадових чи службових осіб, компенсується державою за рішенням суду, а держава має право в порядку регресу вимагати відшкодування своїх збитків у державного службовця. При цьому в Законі України «Про державну службу» закріплено порядок процедури притягнення до відповідальності державних службовців, яка відрізняється від процедури, закріпленої для інших категорій працівників в актах трудового законодавства.

Зазначено про прогалини у вітчизняному законодавстві в цій сфері, зокрема про відсутність регулювання процедури оскарження рішення про притягнення до матеріальної відповідальності державного службовця, визначення віднесення моральної шкоди до збитків в рамках інституту матеріальної відповідальності.
Ключові слова: матеріальна відповідальність, матеріальна шкода, державний службовець, посадова особа, службова особа.

\section{Summary}

Olshevska Yu. M., Berlach A. I. Liability of civil servants under current legislation in Ukraine. - Article.

It is considered the peculiarities of the institution of material responsibility of civil servants for the provisions of the current legislation in the article. The author analysed the features of the procedure, grounds and procedure for imposing liability on civil servants, and described the relationship between the norms of the Law of Ukraine "On Public Service" and the acts of labour law. Consideration was given to the approaches of national scholars to understanding the legal nature of the institution of liability of civil servants, as well as to the significance of the provisions of the Decision of the Plenum of the Supreme Court 14 "On judicial practice in cases of compensation for damage caused to enterprises, institutions and organizations by their employees" dated 29 December 1992 in the application before liability of state employees as subjects of labour law.

The author concludes that liability is a means of ensuring that the officers and officials comply with the requirements of the law and the internal regulations, official instructions and compensation, committed by a public authority or the state in connection with an official misconduct. A characteristic feature of the institution of material responsibility of civil servants is the legal status of civil servants of subjects of law. First of all, according to the constitution, harm is caused by the decisions or activities of a state body, its officials or employees are compensated by the state by a court decision and the state in turn, is entitled, by way of recourse, to claim damages from a civil servant.

At the same time, the Law of Ukraine "On Public Service" lays down the procedure for the prosecution of civil servants, which differs from the procedure laid down for other categories of employees in the acts of labour law. There are gaps in domestic legislation in this area, in particular the lack of regulation of the procedure for appealing against a decision to impose liability on a public servant, determination of the attribution of moral injury to damages within the institution of liability.

Key words: liability, material damage, civil servant, officer, official. 